\title{
Comparison of the effectiveness of positivist psychotherapy with acceptance- based therapy and commitment to the character traits of women with rheumatoid arthritis
}

\author{
Zahra Moradi ${ }^{1}$, Masoud Sadeghi ${ }^{2}$ \\ 1-M.Sc, Department of Psychology, University of Tehran, Tehran, Iran (Corresponding Author). \\ E-mail: zahramoradi1214@gmail.com \\ 2- Assistant Professor, Department of Psychology, Lorestan University, Khorramabad, Iran.
}

Received: 12/03/2020

Accepted: 26/04/2020

\section{Abstract}

Introduction: Rheumatoid arthritis is the most common inflammatory disease of rheumatism.

Aim: The aim of the present study was to compare positive psychotherapy with acceptance and commitment to the empowerment of women with rheumatoid arthritis.

Method: The research method was semi-experimental with pre-test and post-test design with the control group. The statistical population of the study included all women with rheumatoid arthritis in Khorramabad city in 2019. Using the available sampling method, 60 people were selected and randomly divided into three experimental groups 1 (positive treatment) experimental group 2 (acceptance and commitment) and the witness group (20 people in each group) were replaced. Under the same conditions, the pre-test was conducted with a VIA IS questionnaire from all three groups. The experimental groups underwent positive treatment and acceptance and commitment ( 8 sessions, 90-minutes), but the control group did not receive any treatment. The test was then performed on all three groups. The findings were analyzed with SPSS 24 software in two sections: descriptive and inferential statistics.

Results: Results showed that positive treatment and commitment acceptance increased patients' character abilities $(\mathrm{P}<0.05)$, Bonfroni's follow-up test showed that positive treatment had a greater effect on character abilities.

Conclusion: Based on the obtained results, it can be said that positive psychotherapy and acceptance and commitment increase the ability of the character in women with rheumatoid arthritis and positive treatment is more effective. Therefore, these treatments can be used along with medical treatment to improve the ability of these patients.

Keywords: Psychotherapy Positive and optimist, Acceptance and commitment, Characteristics, Joint Rheumatism

\footnotetext{
How to cite this article : Moradi Z, Sadeghi M. Comparison of the effectiveness of positivist psychotherapy with acceptance-based therapy and commitment to the character traits of women with rheumatoid arthritis. Shenakht Journal of Psychology and Psychiatry. $2020 ; 7$ (3): $32-49$. URL: http://shenakht.muk.ac.ir/article-1-923-en.pdf
}

Copyright $@ 2018$ the Author (s). Published by Kurdistan University of Medical Sciences. This is an open access article distributed under the terms of the Creative Commons Attribution-Non Commercial License 4.0 (CCBY-NC), where it is permissible to download, share, remix, transform, and buildup the work provided it is properly cited. The work cannot be used commercially without permission from the journal. 


\section{مقايسه اثربخشى رواندر ماذى مثبت كرا با در مان مبتنى بر يذيرش و تعهد بر توانمنلى هاى منش زنان مبتلا به روماتيسم مفصلى}

زهرا مرادى'، مسعود صادقى ' ا.كارشناس ارشد مشاوره خانواده، گروه روانشناسى، دانشكاه تهران، تهران، ايران (مولف مسئول). ايميل: gmail.com r. استاديار، گروه روانشناسى، دانشكاه لرستان، خرم آباد، ايران.

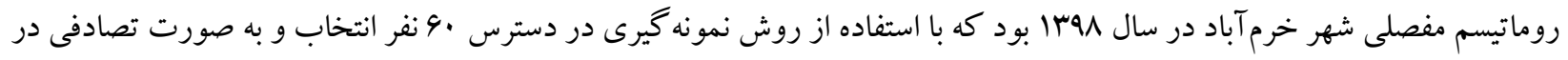

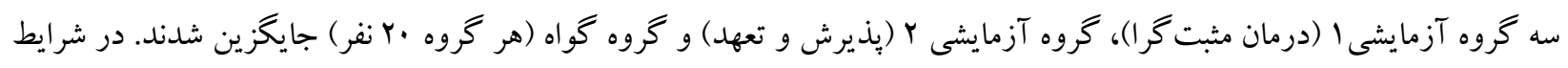

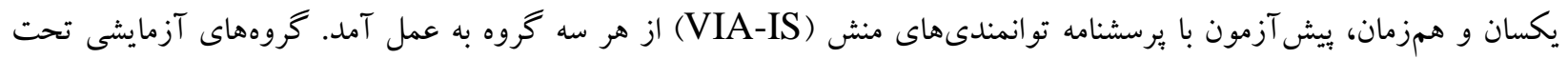

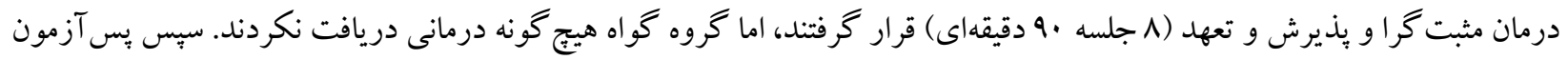
از هر سه گُوه به عمل آمد. يافتها با نرمافزار SPSS YF در دو بخش آمار توصيفى و استنباطى تجزيه و تحليل شد.

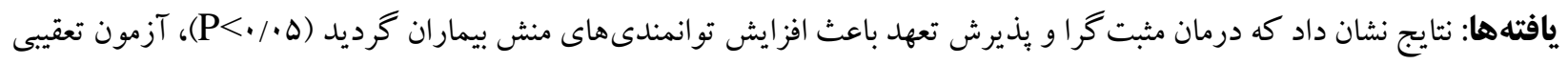
بونغرونى نشان داد، درمان مثبت گرا بر توانمندى هاى منش داراى تأثير بيشترى است.

نتيجه كيرى: براساس نتايج به دست آمده مى توان گفت، رواندرمانى مثبت گرا، مبتى بر يذيرش و تعهد باعث افزايش توانمندىهاى

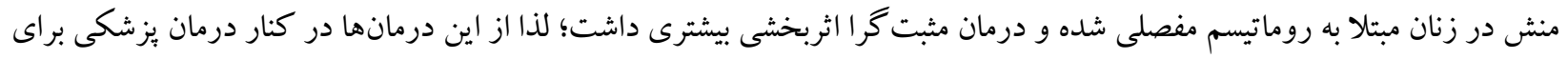
بهبود توانمندى اين بيماران مى توان استفاده كرد. كليدوازهها: رواندرمانى مثبت گرا، يذيرش و تعهد، تو انمندى هاى منش، روماتيسم مفصلى 


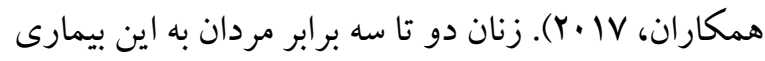

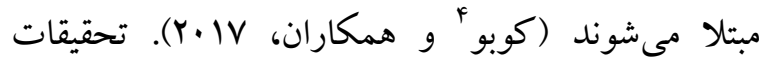
مختلف در حوزه روان نشان دادهاند، مزمن بودن اين بيمارى بر روى متغيرهاى جسمانى، روانشناختى و و بهزيستى اين بيماران تأثير وسيعى مى كذارد (مولوى و همكاران، ها·ץ). با توجه به جنين ماهيتى، افراد مبتلا دجار مشكلات روانشناختى زيادى مىشوند. از اين رو در سالهاى اخير در جهت شناسايى مكانيسمهاى ساز گارانهاى تلاش شده تا افراد مبتلا به درد مزمن بتو انند از طريق آن ها سلامت روانشناختى و توانايى كاركردى خود را حفظ كنند. درد مزمن وضعيتى تحليل برنده است، به گونهاى كه نه تنها تو انمندىهاى بيمار بلكه توانايىهاى

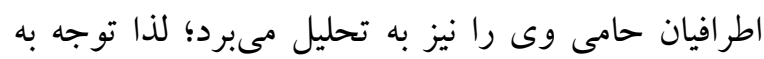

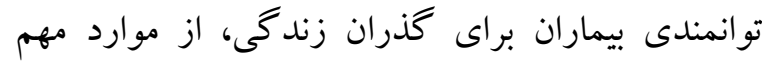
بيماران مبتلا به روماتيسم مفصلى است (فاطمى و منشئى،

$(Y \cdot 19$

توانمندىهاى منش ه يكى از مفاهيم كليدى روانشناسى مثبتنگر است كه ارتباط نزديكى با تجربيات مطلوب و و مثبت دارد و مىتوان آنها را به عنوان صفات مثبت در افكار، احساسات و رفتارها تعريف كرد كه به افراد كمك مى كنند تا كيفيت زندگى و كارايى خود را بهبود

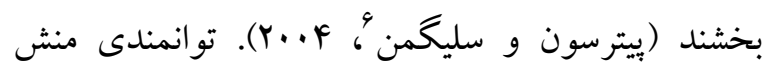
نوعى خودباورى است كه فرد توان انجام كار را به نحو درست در خود مىبيند و تمام تلاش خود را در جهت رسيدن به ملاككهاى خود، به كار مى گيرد (آمونو لو و همكاران، 19 (Y)؛؛ بنابر اين همان طور كه نتايج تحقيقات نشان مىدهد، توانمندى منش يكى از عوامل محافظتى

${ }^{4}$ - Kobue

5 - Character strengths

${ }^{6}$ - Peterson, Seligman

7. Amonoo
بيمارىهاى عضلانى و اسكلتى از جمله شايعترين و

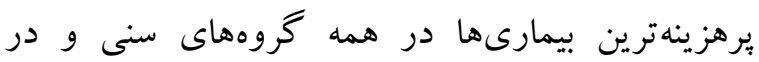

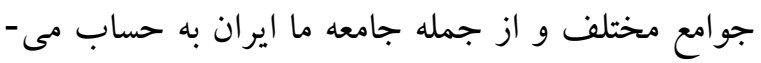
آيند كه باعث ناتوانى، از كار افتادگى، بازنشستخى مجى زودرس و از دست دادن شغل مىشوند (جالشخر و

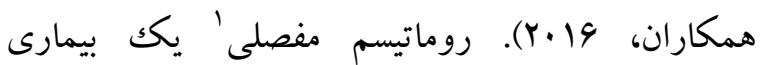
سيستميكك و مزمن است، شيوع اين بيمارى در جهان حدود يك درصد است (بهرامىراد و رافضى، 19 •.Y). علائم بالينى اين بيمارى، سير و ييش آكهى آن در بيماران مختلف، متفاوت است و مىتواند طيف وسيعى از مشكلات از جمله مشكلاتى خفيف در مفاصل تا درگيرى شديد اندامهاى حياتى بدن را در بر بكيرد

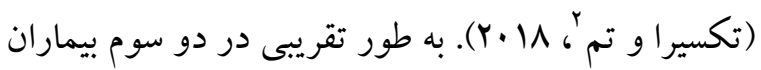

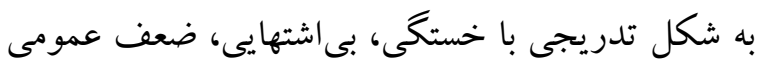
و علائم عضلانى اسكلتى مبهم آغاز شده، هفتهها يا ماهها يايدار مانده و جندين مفصل به خصوص مفاصل دست، مج، زانو و يّا را در گير مى كند. التهاب در مفاصل موجب درد، تورم، خشكى كامل مفاصل درگير و ناتوانى در حركت مىشود. اين وضعيت كاهى مىتواند بسيار دردناكك باشد و علاوه بر تأثير مخربى كه بر مفاصل بدن

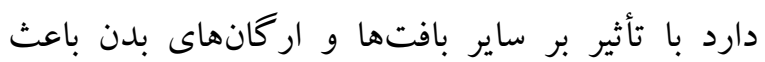
كاهش طول عمر و توانمندى در فرد مىشود (فاطمى و

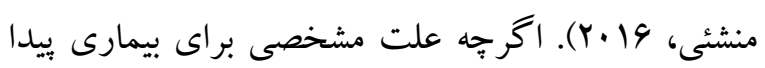
نشده، اما عوامل زنتيكى، وضعيت هورمونى، تغذيه، فاكتورهاى نزادى و وضعيت اقتصادى اجتماعى در ايجاد يا تقويت بيمارى مؤثر است. اين بيمارى مىتواند يكك

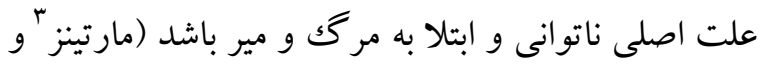

\footnotetext{
'- Rheumatoid Arthritis

${ }^{2}$ - Teixeira, Tam

3 - Martinez
} 
وجود آورده بود. زيربناى نظرى روان درمانى مثبت گراץ

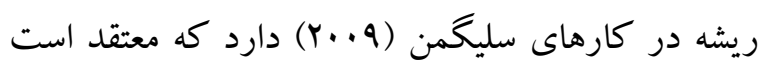
شادى، شامل زندگى لذتمند، متعهدانه و معنادار است و تجربه هيجانهاى مثبتى كه رواندرمانى مثبت كرا بر آن

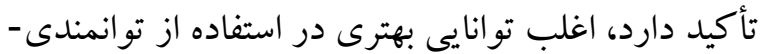

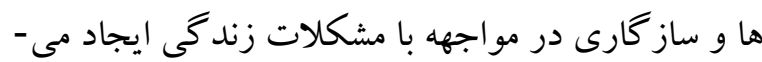
كند (كاسلاس ه و همكاران، IF) از لحاظ تجربى رويكردى معتبر به رواندرمانى است كه توجه ويزهاى به بنا نهادن تو انمندى ها و هيجانهاى مثبت مراجع دارد. مداخلات زيادى در جهارجوب روانشناسى مثبت در دهه اخير بيشنهاد شده است. رواندرمانى مثبتكرا عبارت است از كاربرد مداخلاتى براى مقابله با عدم توانمندى از طريق افزايش هيجانهاى مثبت، بالا بردن سطح درگيرى مثبت در زندگى و افزايش معنا در زندكى، به جاى آن كه به طور مستقيم علائم عدم توانمندى را هدف گيرى نمايند (خدابخش و همكاران،

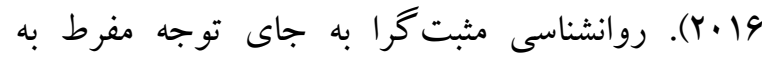
ناتوانىها و ضعفهاى بشرى براى توانايىها انسان مثل

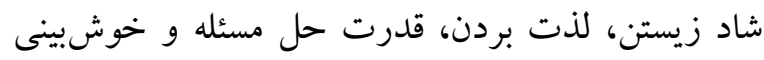
متمركز شده است (صادقى و همكاران، 19 •r). شواهد اوليه به مفيد بودن فنون روانشناسى مثبت گرا براى بيماران مبـتلا بـه دردهـاى مـزمن اشاره كردهاند، اما براى به كارگيرى اين شيوهُ درمانى نياز به بررسىهاى بيشتر است. بدين منظور مىتوان اثربخشى روان درمانىمثبت نَخر را با نتايج درمانى ديخـر رويكردهـاى داراى بشـتوانهُ يثزوهشى كافى مقايسه كرد. از جمله درمانهـاى تأييــ

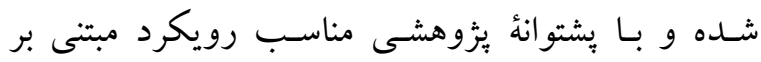

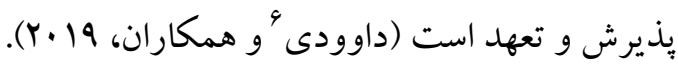

${ }^{4}$ - Positive psychotherapy

5 - Casellas

6. Davoodi
مهم در فرايند رشد و تحول افراد به شمار مىرود. توانمندى منش ديد كاه آدمى را به مفهوم حيات، ابعاد گوناگون زندگى و مرگك و نيستى وسعت مىبخشد

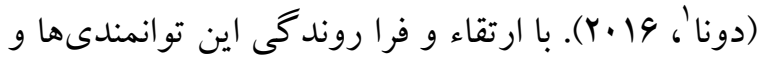
فضيلتهاى برتر از طريق درمان مىتوان به كاهش نشانههاى مشكلات روانشناختى در افراد مبتلا به درد مزمن

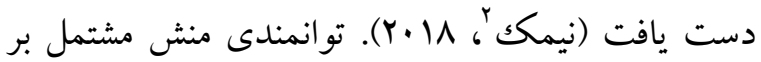
اه FF تو انمندى و ويز گیى در افراد است كه توسط سليخمن (Y..9) در قالب شش تو انمندى كلى طبقهبندى شده و شامل خرد و معرفت (عقل و دانش)، شجاعت، انسانيت

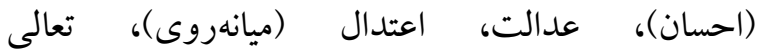

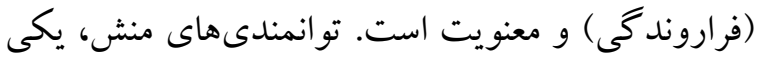
از موضوعات مهم در مسير رشد و تحول افراد است. بر اساس نتايج مطالعات متعدد در اين حوزه، توانمندىهاى منش با بسيارى از شاخصه هاى سلامت و آسيب روانى در

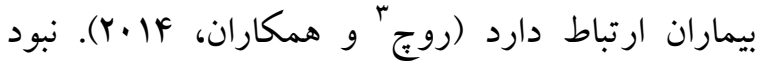
توانمندىهاى منش مى تواند موجب بروز اختلالات روانى شود. در واقع بر اساس ديدكاه روانشناسى، آسيب روانى زمانى ايجاد مىشود كه ظرفيتهاى درونى فرد براى رشد، تكامل و بهزيستى روانى با مشكلات روانشناختى و مسائل اجتماعى مسدود مىشود (جبارى و همكاران، 19 (Y). تو انمندى هاى منش و تجارب مثبت از قبيل رضايتمندى از زندگى جزو توجهات محورى

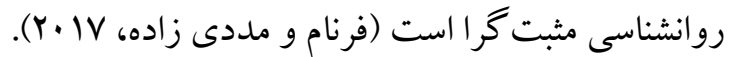

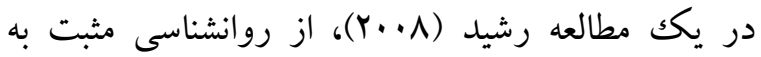
منظور بالا بردن توانمندىها استفاده كرد، نتايج نشان داد كه فنون روانشناسى مثبت در كروه آزمايش تغيير معنادارى در IV تو انمندى مثبت افراد از FF توانمندى، به

\footnotetext{
'- Duan

2- Niemiec

3- Ruch
} 
كنترل ما نيست و به وسيله ما هدايت نمىشود رابطه

بهترى ايجاد كرد (ارجمند قجور و همكاران، 19 •r). در مورد ميزان توانمندىهاى منش بيمار ان در جامعه ايران مطالعات كمى به منظور ارائه درمانهاى مؤثر براى اين

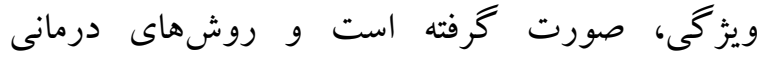
روانشناختى به منظور بهبود توانمندىها ارائه شده و به لحاظ تجربى نيز مورد تأييد واقع شده است. هر جند همه اين درمانها اثر دارد، بين آنها تفاوتهايى از نظر ميزان

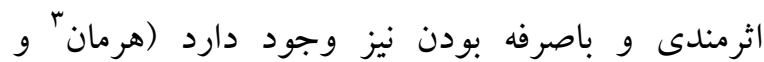
همكاران، F(Y. F). با توجه به مشكلات جسمانى و روانى بيماران مبتلا به بيمارى روماتيسم مفصلى و نظر به اينكه تاكنون هيج يثوهشى به اثر بخشى درمان مبتنى بر بذيرش و تعهل بر توانمندىهاى منش نيرداخته است و همجنين ئزوهشى به منظور بررسى اثربخشى درمان مثبت گرا بر تو انمندىهاى منش بيماران روماتيسم مفصلى انجام نخرفته است؛ لذا بثزوهش حاضر با اهداف اثربخشى

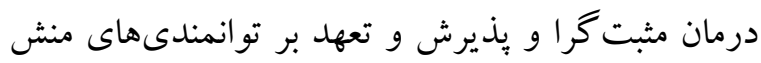
زنان مبتلا به روماتيسم مفصلى، همجِين مقايسه اثربخشى

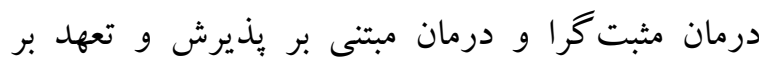

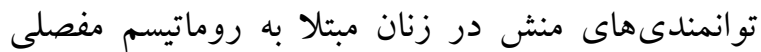

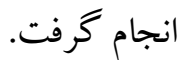

روش اين بزّوهش يكك كار بالينى است كه با روش نيمه آزمايشى و به كار بستن طرح بيش آزمون و بِ بس آزمون

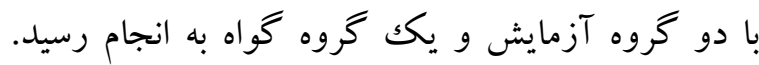
جامعه آمارى يُزوهش شامل كليه زنان مبتلا به روماتيسم

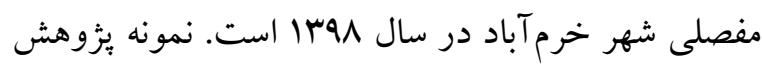

3. Hermann
درمان مبتنى بر يذيرش و تعهد با مخفف اكت (ACT)

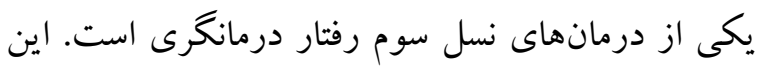
رويكرد در مقايسه با رفتار درمانكرى شناختى تأكيد بيشترى بر بذيرش و تمايل به تجربه رويدادهاى درونى دارد. به جالش نكشيدن افكار منفى و تغيير آنها از ديخر ويز گیىهاى اين رويكرد است. درمان مبتنى بر بذيرش و تعهد، يكى از رفتار درمانىهاى مبتنى بر ذهن آكاهى است كه اثربخشى آن براى درمان طيف گستردهاى از وضعيتهاى بالينى معلوم شده است. اكت اين فرض را دارد كه فرايندهاى روانشناختى ذهن انسان اغلب مخرب و موجب رنج روانشناختى هستند (زهانگك بو همكاران،

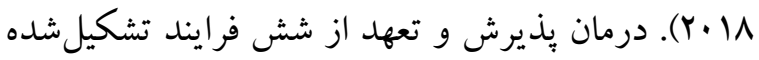
كه اين شش فرايند منجر به انعطاف يذيرى روانشناختى مىشوند. اين شث فرايند عبارتاند از: يذيرش، خنثىسازى (كسلش) و عمل متعهدانه، ارزشها، برقرارى تماس با لحظه جارى، خود زمينهاى (ايز كيان و ميرزاييان، (Y.19). در درمان مبتنى بر بذيرش و تعهد، از درمانجويان خواسته مىشود بيذيرند كه رنج، بخشى از تجربه طبيعى انسان است. با بذيرش رنج به عنوان يكك تجربه، مى توان ياد گرفت كه به آن، ياسخ ساز گارانه ترى داد و بعضى از ارتباطات كلامى را با آن تغيير داد (ازهاى و

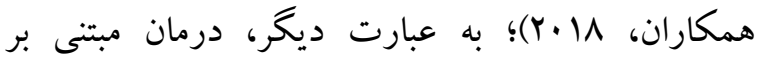
يذيرش و تعهد كمكك به افراد جهت برخوردارى از يك سك

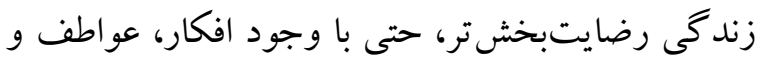
احساسات نامطلوب است. طبق ديدگاه درمان مبتنى بر يذّيرش و تعهل، راهى براى حذف كردن افكار مربوط به دردهاى مزمن وجود ندارد، اما مىتوان با آنجه تحت برى

${ }^{1}$ - Acceptance and Commitment Therapy ${ }^{2}$ - Zhang 
تو انمندى هاى منش مجدداً به عنوان بِ آزمون توسط هر

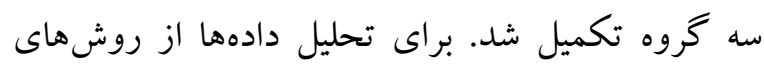
آمار توصيفى نظير فراوانى، درصد، ميانگين و انحراف استاندارد و از روشهاى آمار استباطى شامل تحليل كواريانس جند متغيره، تحليل كواريانس تكك متغيره و آزمون تعقيبى بونفرونى استفاده شد. دادهها بهوسيله نسخه نرمافزار تحليل آمارى SPSS تحليل شد.

ابزار

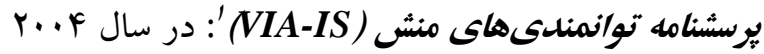
توسط بيترسون و سليخمن منتشر شد. فرم كوتاه اين آزمون كه FF سؤال است كه طبق طيف ليكرت از 1

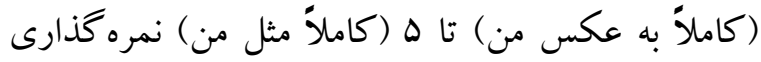
مىشود. اين برسشنامه YF توانمندى منش كه از شش فضيلت عمومى جهانى منتج شدهاند را مىسنجد. اين شش مؤلفه عبارتاند از: خرد و دانش، شجاعت، انساندوستى، عدالت، اعتدال (ميانهروى) و تعالى لنى (فراروندگى). اين برسشنامه براى اولين بار در ايران

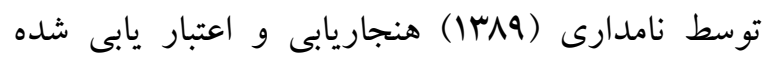
است. يايايى اين مقياس به روش باز آزمايى بين Yو/، تا

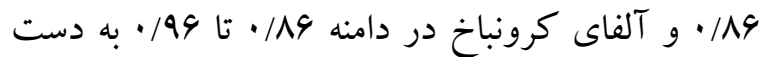
آمله است.

يافتها

در يُزوهش حاضر دامنه سنى زنان مورد بررسى قرار

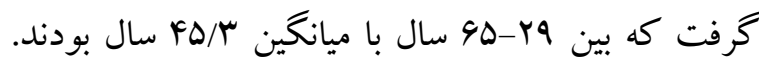
سابقه بيمارى روماتيسم مفصلى آنها بين Y تا ها سال و
به صورت در دسترس از بين كليه زنان مبتلا روماتيسم

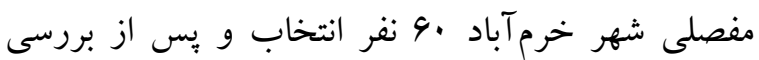
ملاكك ورود (تشخيص بيمارى روماتيسم مفصلى توسط يزشك متخصص، سابقه بيش از يكك سال بيمارى روماتيسم، رضايت به شركت داشتن در جلسات درمانى و نداشتن اختلالات روانيزشكى) و ملاككهاى خروج (غيبت r جلسه يا بيشتر، داشتن اختلال روانى و عدم تمايل شركت در جلسات) به صورت تصادفى در سه گروه آزمايشى شماره ا (تحت درمان مثبت گرا)، كروه آزمايشى شماره r(تحت درمان مبتنى بر بذيرش و

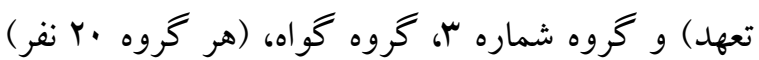

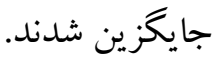
براى بثزوهش حاضر ابتدا كد اخلاق از دانشگاه علوم يزشكى شهرستان خرم آباد اخذ و سيس مقدمات لازم براى انجام كار آماده كرديد. يِيش از انجام مداخلات، به توضيح دلايل و نحوه انجام بزّوهش براى بيماران برداخته شد و با آنها اطمينان داده شد كه اطلاعات آنها محرمانه خو اهد ماند و بِ از اعلام رضايت آكاهانه بيمار (شامل اين مورد است كه فرد هر زمان كه بخواهد مى تواند از ادامه جلسات درمانى انصراف دهد و هيج عواقبى براى او ندارد) جلسات شروع شد. در ابتدا هر دو گروه آزمايشى و يكى گروه گواه در شرايط يكسان برسشنامه توانمندىهاى منش را به عنوان بيش آزمون تكميل

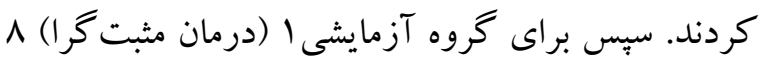

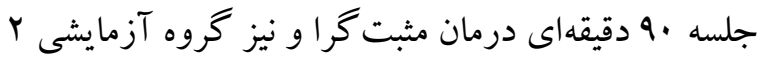
(درمان مبتنى بر بذيرش و تعهد) ^ جلسه •q دقيقهاى درمان مبتنى بر بذيرش و تعهد، به صورت يكك جلسه در هفته انجام يذيرفت گروه گُواه هيج مداخلهاى دريافت نكردند. پِس از اتمام جلسات درمانى، برسشنامه

\footnotetext{
1. Values In Action Inventory of Strengths
} 
مرحله يِش آزمون و يس آزمون اندازه گيرى شده است كه نتايج آن در جدول شماره ا، ارائه گرديده است.
با ميانگين 9/ه سال بود. از بين ·9 نفر آزمودنى بثزوهش حاضر 4س نفر متأهل، سا نفر بيوهو ال النفر مطلقه بودند. ميانگين و انحر اف استاندارد توانمندىهاى منش براى هر بره

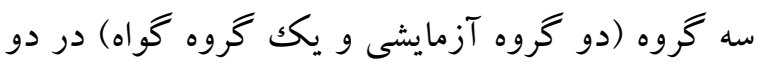

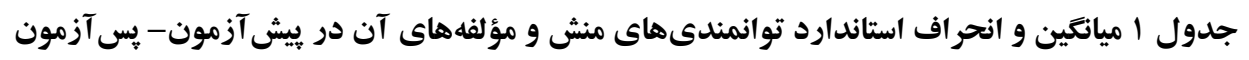
دو كروه آزمايشى و يك كروه توان مواه

\begin{tabular}{|c|c|c|c|c|c|}
\hline \multicolumn{2}{|c|}{ ֶׁ آزمون } & \multicolumn{2}{|c|}{ ييش آزمون } & \multirow{2}{*}{\multicolumn{2}{|c|}{ عضويت كروهى }} \\
\hline انحراف & ميانكين & انحراف & ميانكين & & \\
\hline استاندارد & & استاندارد & & & \\
\hline$r / r v$ & $V N / 9 \Delta$ & $r / I V$ & $\Delta F / T \Delta$ & كروه مثبت گرا & \\
\hline$\Delta / a r$ & $V I / A V$ & $r / \Delta 9$ & $\Delta r / \Lambda$ & كروه اكت & توانمندىهاى منش كلى \\
\hline $1 / \Delta V$ & $\Delta F / T Y$ & $r / \cdot r$ & $\Delta r / v \wedge$ & كروه گواه & \\
\hline$r / \Delta 9$ & $\mid F / 4$ & $1 / \Delta V$ & $1 . / 90$ & كروه مثبت گرا & \\
\hline $1 / 90$ & $1 r / 9$ & $1 / 49$ & $9 / v$ & كروهاكت & خرد و دانش \\
\hline $1 / 49$ & $1 \cdot / r \Delta$ & $1 / \pi 4$ & Q/vQ & كروه كواه & \\
\hline $1 / 91$ & $1 r / 9$ & $1 / \pi 9$ & $\Lambda / \Delta \Delta$ & كروه مثبت گرا & \\
\hline $1 / N r$ & $\mid r / \cdot \Delta$ & $.19 \mathrm{~V}$ & N/TS & كروهاكت & شجاعت \\
\hline$\cdot / 19$ & $9 / 1$ & .190 & $\Lambda / v$ & كروه گواه & \\
\hline $1 / 91$ & $11 / .0$ & $\cdot / M$ & $V / \Delta \Delta$ & كروه مثبت گرا & \\
\hline $1 / 4 \Delta$ & $1 \cdot / r$ & $\cdot|A|$ & V/AD & كروه اكت & انسان دوستى \\
\hline ./va & $V / A$ & $\cdot / \lambda r$ & $V / r$ & كروه گواه & \\
\hline 1/or & $1 . / 90$ & $\cdot / 94$ & $V / \Delta$ & كروه مثبت گرا & \\
\hline $1 / \pi$ & Q/9Y & •/Ar & $V / r$ & كروه اكت & عدالت \\
\hline$\cdot / M$ & $V / F Y$ & - /VG & V/or & كروه گواه & \\
\hline $1 / \pi$ & $\mid r / 4$ & $\cdot / \mathrm{Va}$ & 9 & گروه مثبت گرا & \\
\hline $1 / 01$ & $11 / 9 \Delta$ & .194 & $\Lambda / v \Delta$ & كروه اكت & اعتدال \\
\hline$\cdot / V^{k}$ & $1 / 90$ & $\cdot / 4 A$ & $\Lambda / \Lambda$ & كروه گواه & \\
\hline $1 / 94$ & $19 / 4$ & $\cdot 119$ & $11 / r$ & گروه مثبت گرا & \\
\hline$r / 9 \mathrm{~V}$ & $\mid F / Y \Delta$ & . $/ A r$ & $1 . / 90$ & كروهاكت & تعالى \\
\hline$\cdot / M$ & $11 / 1$ & $\cdot / v^{4}$ & $1 \cdot / 1$ & كروه گواه & \\
\hline
\end{tabular}


لوين، نمودار براكندگى براى خطى بودن رابطه بين

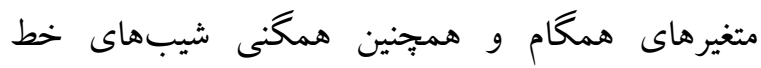

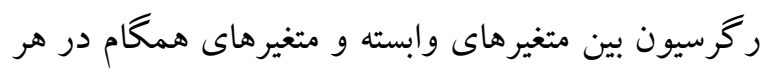

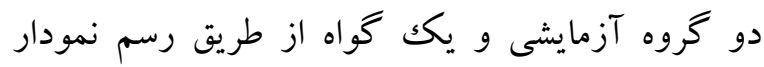
يراكنش بررسى و تائيد شد. براى نشان دادن اثربخشى

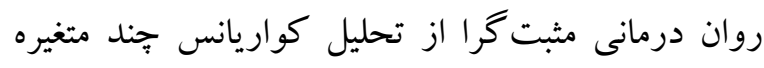

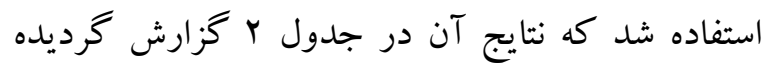

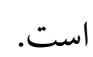

همانطور كه در جدول ا، نشان داده شده است تو انمندى هاى منش و خرده مؤلفههاى آن در هر دو گروه آزمايشى درمان مثبت گرا و يذيرش و تعهل در مرحله

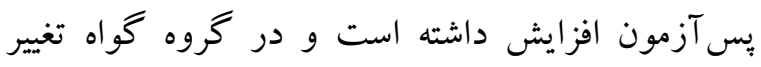

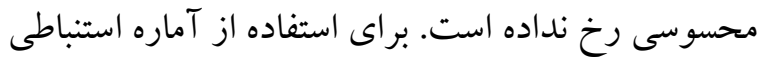

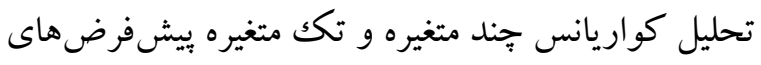

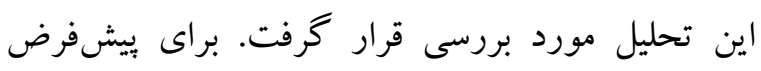

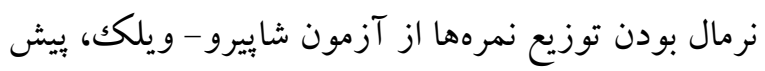
فرض تساوى واريانسها (يس آزمون) با استفاده از آزمون

جدول ب نتايج تحليل كواريانس جند متغيره براى توانمندىهاى منش در مرحله يس آزمون درمان مثبت

\begin{tabular}{|c|c|c|c|c|c|c|c|c|}
\hline توان & اثدازه & معنادارى سطح & $\mathbf{F}$ & درجه آزادى & درجه آزادى & ارزش & آزمون & \multirow{5}{*}{ كروه } \\
\hline 1 & .199 &.$/ .1$ & FN/FA & 9 & rV & .199 & اثر بيلايى & \\
\hline 1 & .199 & $\cdot / \cdot 1$ & 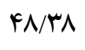 & 9 & rV & $\cdot / A T$ & لامبدايى ويلكز & \\
\hline 1 & .199 &.$\cdots 1$ & $F \wedge /{ }^{\prime} \Lambda$ & 9 & rV & Q/VD & هتليك & \\
\hline 1 & $\cdot 199$ & $\cdot / \cdot 1$ & FA/ & 9 & rV & Q/VD & بزرك ترين ريشه & \\
\hline
\end{tabular}

آزمايشى مثبت گرا با گروه گواه تفاوت معنادارى وجود

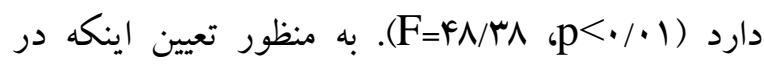
كدام يكك از مؤلفهاى توانمندىهاى منش تفاوت

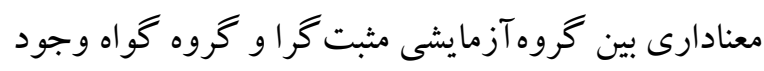
دارد از آزمون تحليل كواريانس تكك متغيره استفاده شد كه نتايج آن در جدول بارائه گرديده است.
همانطور كه در جدول Y مشاهده مى شود يس از خارج

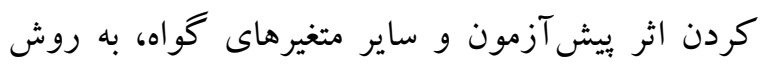
تحليل كواريانس جند متغيره، اثر معنىدارى براى عامل عضويت گروهى وجود دارد. اين اثر جند متغيره نشان مىدهد كه درمان مثبت گرا بر توانمندىهاى منش تأثير دارد و بين مؤلفههاى توانمندىهاى منش بيماران كروه

\begin{tabular}{|c|c|c|c|c|c|c|c|c|}
\hline توان & اندازه اثر & معنادارى سطح & $\mathbf{F}$ & مجذورات ميانكين & آزادى درجه & مجزورات مجموع & منبع تغييرات & متغير \\
\hline ./r &.$/ . r$ & . A &.$/ 90$ & $r / N$ & 1 & $r / N$ & بِيش آزمون & \\
\hline$\cdot / 99$ & $\cdot / \Delta \Delta$ & $\cdot / \cdot 1$ & $r \Delta / \Lambda$ & $191 / 4$ & 1 & $191 / 4$ & عضويت گروهى & خرد و دانش \\
\hline .119 &.$/ \cdot r$ & $\cdot / \mu 1$ & $1 / \cdot F$ & Y/AD & 1 & Y/AD & يِي آزمون & شجاعت \\
\hline 1 & . $/ \Delta r$ & $\cdot / \cdot \cdot 1$ & $r \mu / 1$ & $11 / / \mu r$ & 1 & $11 / / \pi r$ & عضويت گروهى & \\
\hline
\end{tabular}




\begin{tabular}{|c|c|c|c|c|c|c|c|c|}
\hline$\cdot / \cdot 1$ & .1 .9 & $\cdot / \Delta 9$ & $\cdot / M F$ & $\cdot / \Delta r$ & 1 & $\cdot / \Delta r$ & يِيش آزمون & \multirow{2}{*}{ انسان دوستى } \\
\hline 1 & .190 & $\cdot / \cdots 1$ & $99 / 9 V$ & $1 \cdot v / r q$ & 1 & $1 \cdot v / r q$ & عضويت گروهى & \\
\hline$\cdot / r r$ & $\cdot 110$ & $\cdot / \mathrm{r}$ & $V / \cdot r$ & $r q / 9 \mathrm{~V}$ & 1 & $r q / q V$ & بيش آزمون & \multirow[t]{2}{*}{ عدالت } \\
\hline 1 & $\cdot / 4 \Delta$ &.$/ \cdots 1$ & rו/ & $|V D / 9|$ & 1 & $|V D / 9|$ & عضويت گروهى & \\
\hline$\cdot / \cdot \wedge$ & $\cdot 1 \cdot 1$ & $\cdot / \Delta \Lambda$ & ( & $\cdot / 99$ & 1 & $\cdot / 99$ & ييش آزمون & \multirow[t]{2}{*}{ اعتدال } \\
\hline$\cdot / 99$ & $\cdot / \Delta V$ & $\cdot / \cdots 1$ & $F D / Y F$ & rr/ •rו & 1 & سr/. & عضويت گروهى & \\
\hline$\cdot / \cdot \Delta$ & $\cdot / \cdot 1$ & $\cdot / 9 r$ & $.1 \cdot 9$ & $\cdot / \Delta r$ & 1 & $\cdot / \Delta r$ & بيش آزمون & \multirow[t]{2}{*}{ تعالى } \\
\hline 1 & $\cdot / D F$ & $\cdot / \cdot 1$ & Fr/94 & KFF/Q & 1 & $Y F F / Q$ & عضويت گروهى & \\
\hline
\end{tabular}

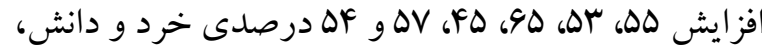
شجاعت، انسان دوستى، عدالت، اعتدال و تعالى در بيماران در گروهآزمايشى مثبت گرا در مرحله بِ آزمون شده است. به منظور بررسى اندازه اثر درمان مبتنى بر يذيرش و تعهد از تحليل كواريانس جند متغيره بهره كرفته شد كه نتايج آن در جدول كا، نشان دادهشده است.
با توجه به نتايج جدول سا، با كنترل نمرات بيش آزمون،

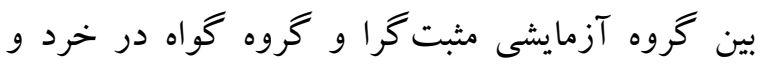
دانش، شجاعت، انسان دوستى، عدالت، اعتدال و تعالى زنان مبتلا به روماتيسم مفصلى در مرحله يس آزمون تفاوت معنادارى وجود دارد ( ( •/p). با توجه به نتايج فوق مىتوان نتيجه گرفت كه درمان مثبت گرا موجب

جدول † نتايج تحليل كوار يانس جند متغيره براى توانمندىهاى منش در مرحله يس آزمون درمان يذيرش و تعهد

\begin{tabular}{|c|c|c|c|c|c|c|c|c|}
\hline توان & اندازه اثر & معنادارى سطح & $\mathbf{F}$ & درجه آزادى & آزادى خطها & ارزش & آزمون & \multirow{5}{*}{ كروه } \\
\hline.$/ 99$ & .194 &.$/ . \cdot 1$ & $r \cdot / W$ & 9 & rv & .194 & اثر بيلايى & \\
\hline$\cdot / 99$ & .194 & $\cdot / \cdot \cdot 1$ & $r \cdot / V V$ & 9 & rV & 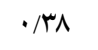 & لامبدايى ويلكز & \\
\hline.$/ 99$ & .194 &.$/ \cdot 1$ & $r \cdot / W V$ & 9 & rV & $r / 4 \&$ & هتليك & \\
\hline$\cdot / 99$ & .194 &.$/ . .1$ & $r \cdot / V V$ & 9 & rV & $r / 4 \&$ & بزر كترين ريشه & \\
\hline
\end{tabular}

معنادارى وجود دارد ( F=r./VV تعيين اينكه در كدام يكك از مؤلفهاى توانمندىهاى

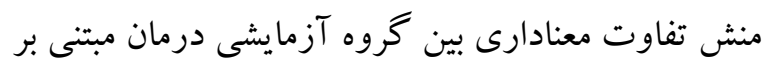
يذيرش و تعهد و گرووه گو اه وجود دارد از آزمون تحليل كواريانس تكك متغيره استفاده شد كه نتايج آن در جدول نول هارائه كرديده است.
همان طور كه در جدول F، مشاهده مىشود يس از خارج كردن اثر بيش آزمون و ساير متغيرهاى گواه، به روش تحليل كواريانس جند متغيره، اثر معنىدارى براى عامل عضويت گروهى وجود دارد. اين اثر جند متغيره نشان مىدهد كه درمان يذيرش و تعهد بر توانمندىهاى منش تأثير دارد و بين مؤلفهاى توانمندىهاى منش بيماران

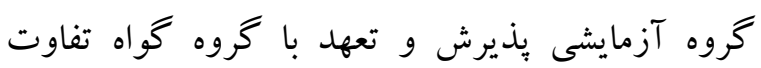




\begin{tabular}{|c|c|c|c|c|c|c|c|c|}
\hline آمارى & اندازه & سعادارى & $\mathbf{F}$ & مجانكين & درآدى & مجزورات & منبع تغيير ات & متغير \\
\hline.$/ 14$ & $.1 \cdot 9$ & $\cdot|q|$ & $\cdot 19 \mathrm{~V}$ & $F / 9 r$ & 1 & $F / 9 r$ & بيش آزمون & \\
\hline$\cdot / 99$ & $\cdot / 41$ & $\cdot / \cdots 1$ & $r 9 / \cdot 0$ & $191 / \Delta \Delta$ & 1 & $191 / \Delta \Delta$ & عضويت گروهى & خرد \\
\hline • /49 & .1 .9 & $\cdot / 1$ & r/VG & $\Delta / 9 \mathrm{~V}$ & 1 & $\Delta / 9 \mathrm{~V}$ & ييش آزمون & شجاعت \\
\hline$\cdot / 99$ & $\cdot / 4 r$ &.$/ \cdot 1$ & $r(/ \Delta)$ & $\Delta / / 91$ & 1 & $\Delta \wedge / 9)$ & عضويت گروهى & \\
\hline$\cdot / \cdot V$ & $\cdot / \cdot \Delta$ & .190 & $\cdot|r|$ & $\cdot / r \Lambda$ & 1 & $\cdot / r \Lambda$ & ييش آزمون & انسان \\
\hline 1 & $\cdot / \Delta \Lambda$ & $\cdot / \cdots 1$ & $\Delta Y / F r$ & VR/AF & 1 & VT/AF & عضويت گروهى & دوستى \\
\hline$\cdot / r \Delta$ & $\cdot / \cdot \Delta$ &.$/ 1 \Lambda$ & $|/ \wedge|$ & $r / Y G$ & 1 & r/rG & يِيش آزمون & عدالت \\
\hline 1 & $\cdot 109$ &.$/ \cdots 1$ & $\Delta 1 / V 1$ & GF/VG & 1 & GF/VG & عضويت گروهى & \\
\hline$\cdot / \mu F$ & .1 .9 &.$/ 11$ & $r / 91$ & G/V9 & 1 & G/VA & ييش آزمون & اعتدال \\
\hline$\cdot / 99$ & $\cdot / F V$ &.$\cdots 1$ & MT/AV & $1 N / 19$ & 1 & $1 N / 19$ & عضويت گروهى & \\
\hline .1 .9 & $\cdot / \cdot r$ & $\cdot / V \Delta$ &.$/ 11$ & $\cdot|F|$ & 1 & $\cdot / 41$ & ييش آزمون & تعالى \\
\hline$\cdot / 91$ & $\cdot / 4 r$ & $\cdot / \cdot 1$ & YN/YN & $11 r / 49$ & 1 & $11 r / 49$ & عضويت گروهى & \\
\hline
\end{tabular}

خرد و دانش، شجاعت، انسان دوستى، عدالت، اعتدال و تعالى در بيماران در گروهآزمايشى يذيرش و تعهد در مرحله يس آزمون شده است. براى نشان دادن تفاوت بين اثر بخشى درمان مثبت كرا و مبتنى بر يذيرش و تعهد بر توانمندىهاى منش بيماران از آزمون تعقيبى بنفرونى استفاده شده كه نتايج آن در جدول و، گزارش گرديده

است.
با توجه به نتايج جدول ه، با كنترل نمرات بيش آزمون، بين كروه آزمايشى درمان يذيرش و تعهد و گروه گواه در خرد و دانش، شجاعت، انسان دوستى، عدالت، اعتدال و تعالى زنان مبتلا به روماتيسم مفصلى در مرحله يّ آزمون تفاوت معنادارى وجود دارد ( ( • به نتايج فوق مىتوان نتيجه كرفت كه درمان يذيرش و

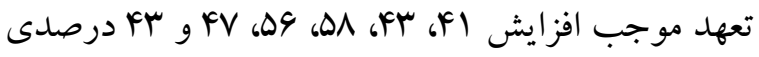

جدول و نتايج آزمون تعقيبى بنفرونى براى تعيين اثر مداخله كروههاى آزمايشى درمان مثبت كرا، درمان اكت

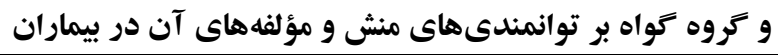

\begin{tabular}{|c|c|c|c|c|c|c|c|}
\hline كران & كران & معنادارى سطح & استاندارد افحر & تفاوت ميانكين & J J J J J J & I & مؤلفهها \\
\hline $1 . / .9$ & $r / r$. & $\cdot / \cdots 1$ & $1 / \pi V$ & G/VI" & اكت & مثبت گرا & \\
\hline YA/Vq & $r r / \cdot \Lambda$ & $\cdot / \cdots \cdot 1$ & $1 / \pi V$ & $r \Delta / \digamma^{*}$ & كواه & & توانمندىهاى منش كلى \\
\hline$-1 \cdot / \cdot 9$ & $-r / r$. & $\cdot / \cdots 1$ & $1 / r V$ & $-9 / V I^{*}$ & مثبت كرا & اكت & \\
\hline$r r / \cdot q$ & $10 / \mu$. & $\cdot / \cdots \cdot 1$ & $1 / T V$ & $M / V^{*}$ & كواه & & \\
\hline$-Y \wedge / V q$ & $-Y Y / \cdot \wedge$ & $\cdot 1 \cdots \cdot 1$ & $1 / T V$ & $-r \Delta / \mathscr{f}^{*}$ & مثبت كرا & كواه & \\
\hline$-Y Y / \cdot 9$ & $-1 \Delta / \mu$ & $\cdot / \cdots \cdot 1$ & $1 / T V$ & $-\mid \Lambda / V^{*}$ & 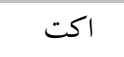 & & \\
\hline $1 / 99$ &.$/ 99$ & 1 & .19. & $\cdot / \Delta$ & 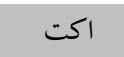 & مثبت گرا & \\
\hline $9 / 1 F$ & $r / 10$ & $\cdot / \cdots \cdot 1$ & .19 & $F / 90^{*}$ & كواه & & خرد \\
\hline
\end{tabular}




\begin{tabular}{|c|c|c|c|c|c|c|c|}
\hline.$/ 99$ & $-1 / 99$ & 1 & $\cdot 19$ & $-\cdot / 10$ & مثبت گرا & اكت & \\
\hline$\Delta / 94$ & $r / 90$ & $\cdot / \cdots \cdot 1$ & $\cdot / 9$ & $f / l 0^{*}$ & كواه & & \\
\hline$-9 / 1 f$ & $-r / 10$ & $\cdot / \cdots \cdot 1$ & $\cdot 19$ & $-F / 90^{*}$ & مثبت گرا & كو اه & \\
\hline$-Y / 90$ & $-\Delta / 94$ & $\cdot / \cdots+1$ & $\cdot / 9$ & $-F / 10^{*}$ & اكت & & \\
\hline$-1 / \mathrm{W}$ & $-\cdot 19 \mathrm{~V}$ & $\cdot|\wedge|$ & $\cdot / 4 q$ & $\cdot / \Delta \Delta$ & اكت & مثبت گرا & \\
\hline$r / 9 r$ & $T / F V$ & $\cdot / \cdots 1$ & $\cdot / 49$ & $r / v^{*}$ & كواه & & شجاعت \\
\hline $.19 \mathrm{~V}$ & $-1 / W V$ & $\cdot|\wedge|$ & $\cdot / 4 q$ & $\cdot / \Delta \Delta$ & مثبت كرا & اكت & \\
\hline$F / r V$ & I/9Y & $\cdot / \cdots+1$ & $\cdot / 4 q$ & $r / l 0^{*}$ & كواه & & \\
\hline$-Y / F V$ & $-F / A Y$ & $\cdot / \cdots \cdot 1$ & $\cdot / 4 q$ & $-r / V^{*}$ & مثبت گرا & كو اه & \\
\hline$-F / M V$ & $-1 / 9 r$ & $\cdot / \cdots \cdot 1$ & $\cdot / 4 q$ & $-r / 10^{* *}$ & اكت & & \\
\hline $1 / v 9$ & $-\cdot / 49$ & $\cdot / Y F$ & $\cdot / A r$ & $\cdot / V \Delta$ & اكت & مثبت گرا & \\
\hline$F / v q$ & $r / V$ & $\cdot / \cdots \cdot 1$ & $\cdot / F Y$ & $r / V Q^{*}$ & كواه & & انسان دوستى \\
\hline$\cdot / r q$ & $-1 / \sqrt{ } 9$ & $\cdot / Y F$ & $\cdot / F r$ & $\cdot / V \Delta$ & مثبت گرا & اكت & \\
\hline$f / \cdot F$ & $1 / 90$ & $\cdot / \cdots 1$ & $\cdot / F r$ & $r^{*}$ & كو اه & & \\
\hline$-Y / V$ & $-F / v q$ & $\cdot / \cdots 1$ & $\cdot / F r$ & $-r / V \Delta^{*}$ & مثبت گرا & كو اه & \\
\hline$-F / \cdot F$ & $-1 / 9 \Delta$ & $\cdot / \cdots \cdot 1$ & $\cdot / F r$ & $-r^{*}$ & اكت & & \\
\hline I/VF & $-\cdot / T F$ & $\cdot / Y I$ & $\cdot|q|$ & $\cdot / V \Delta$ & اكت & مثبت گرا & \\
\hline$F / Y F$ & $r / T \Delta$ & $\cdot / \cdots 1$ & $\cdot|+|$ & $r / r Q^{*}$ & كواه & & \\
\hline$-I / V F$ & $\cdot / Y F$ & $\cdot / r 1$ & $\cdot|+|$ & $-\cdot / V \Delta$ & مثبت گرا & اكت & عدالت \\
\hline$r / 4 q$ & $1 / 0$ & $\cdot / \cdots+1$ & $\cdot|4|$ & $r / D^{*}$ & كو اه & & \\
\hline$-Y / Y Q$ & $-F / Y F$ & $\cdot / \cdots 1$ & $\cdot|q|$ & $-r / r \Delta^{*}$ & مثبت گرا & كواه & \\
\hline$-1 / 0$ & $-r / \& q$ & $\cdot / \cdots \cdot 1$ & $\cdot|4|$ & $-Y / Q^{*}$ & اكت & & \\
\hline$r / M$ & $1 / \cdot 1$ & $\cdot / \cdots \cdot 1$ & $\cdot / \pi \Lambda$ & $1 / 90^{*}$ & اكت & مثبت گرا & \\
\hline$\Delta / 9 \Lambda$ & $r / \Lambda 1$ & $\cdot / \cdots+1$ & $\cdot / \mu$ & $F / V Q^{*}$ & كواه & & اعتدال \\
\hline$-1 / \cdot 1$ & $-r / M$ & $\cdot / \cdots 1$ & $\cdot / \Gamma \Lambda$ & $-1 / 90^{*}$ & مثبت گرا & اكت & \\
\hline$r / v r$ & 1/A9 & $\cdot / \cdots \cdot 1$ & $\cdot / \Gamma$ & $r / \Lambda^{*}$ & كواه & & \\
\hline$-r / A I$ & $\Delta / 9 \Lambda$ & $\cdot / \cdots 1$ & $\cdot / \pi \wedge$ & $F / V \Delta^{*}$ & مثبت گرا & كواه & \\
\hline$-1 / 19$ & $-r / N r$ & $\cdot / \cdots 1$ & $\cdot / \Gamma$ & $-Y / \Lambda^{*}$ & اكت & & \\
\hline$r / 91$ & .191 & $\% r$ & $\cdot 109$ & $Y / 1 Q^{*}$ & اكت & مثبت گرا & \\
\hline $9 / 99$ & $F / \cdot r$ & $\cdot / \cdots+1$ & $\cdot / 09$ & $\Delta / \Delta^{*}$ & كواه & & تحالى \\
\hline-.191 & $-r / 91$ & $\cdot / \cdot r$ & $\cdot / \Delta 9$ & $-Y / 10^{*}$ & مثبت گرا & اكت & \\
\hline$F / \wedge)$ & $1 / M$ & $\cdot / \cdots 1$ & $\cdot / 09$ & $r / r \Delta^{*}$ & كواه & & \\
\hline$-F / \cdot r$ & $-9 / 99$ & $\cdot / \cdots 1$ & $\cdot / \Delta 9$ & $-\Delta / \Delta^{*}$ & مثبت گرا & كواه & \\
\hline$-1 / M$ & $-F / \Lambda \mid$ & $\cdot / \cdots+1$ & $\cdot / \Delta 9$ & $-\Gamma / \Gamma \Delta^{*}$ & اكت & & \\
\hline
\end{tabular}

تومان طور كه در جدول 9، نشان داده شده، در نمرات 
در تبيين يافته هاى اين يزوهش مىتوان كفت كه درمان

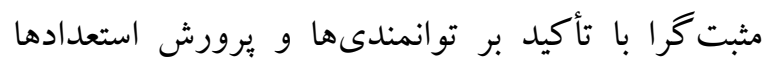
توانسته در بهبود توانمندى و افزايش احساس و هيجانات مثبت و تفكر مثبت مؤثر باشد. رواندرمانى مثبت گرا، بازنمايى كنندهى تعهد جديدى در بثوهش است كه در آن به منبع سلامت روانى توجه و تأكيد مى كنند (جبارى

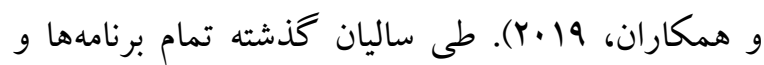

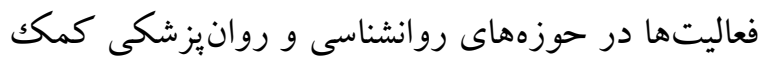
به افراد براى برطرف كردن اختلالات و بيمارىها بود.

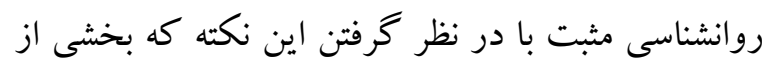
رسالت روانشناسى كمكك به افراد است تا بتوانند به حد

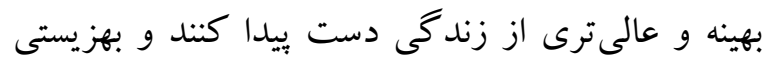
روانى را تجربه كنند، روشهاى درمانى خود را بنا نهاده است. همجِنين رواندرمانى مثبت، از لحاظ تجربى رونى رويكردى معتبر به رواندرمانى است كه توجه ويزهاى به بنا نهادن توانمندىها و هيجانهاى مثبت دارد (فرنام و

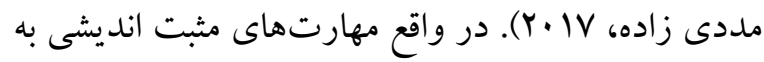
افراد كمكك مى كند در كنترل و تغيير افكار منفى يا نادرست بهتر عمل كنند و هدف اصلى از اين درمان اين است كه افراد حتى از بدترين شرايط، بهترين نتيجه را

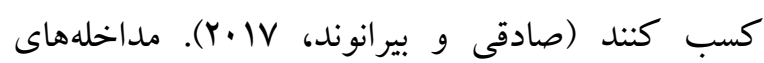
رواندرمانى مثبت گرا از طريق افزايش افكار و رفتارهاى مثبت به افراد در جبران برخى خطرات و كاهش

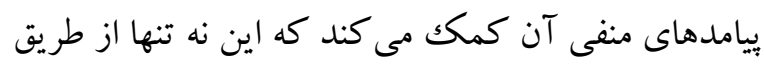
كاهش هيجانات منفى بلكه به صورت مستقيم نيز به افزايش و رشد توانمندىهاى منش در افراد منجر مىشود (عصارزاد گان و رئيسى، (Y) (Y). نتايج يزوهش حاضر نشان داد كه درمان مبتنى بر يذيرش و تعهد باعث افزايش توانمندىهاى منش و مؤلفههاى آن
منش كلى و مؤلفهاى اعتدال و تعالى اثربخشى بيشترى نسبت به درمان بذيرش و تعهد داشته است. در مؤلفههاى خرد و دانش، شجاعت، انسان دوستى و عدالت بين دو كروه آزمايشى (مثبت گرا و وِذيرش و تعهد) تفاوت معنادارى مشاهده نشد. همجِنين نتايج نشان مىدهد كه هر دو مداخله درمانى مثبت گرا و يذيرش تعهل بر توانمندى هاى منش و مؤلفههاى آن (خرد و دانش، شجاعت، انسان

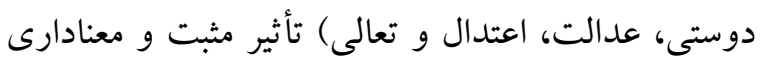
دارد و باعث افزايش توانمندىهاى منش در زنان مبتلا به روماتيسم مفصلى گرديد. هدف يزوهش حاضر بررسى اثربخشى درمان مثبت گراو يذيرش و تعهد بر توانمندىهاى منش زنان مبتلا به روماتيسم مفصلى و همجنين مقايسه اثربخشى درمان مثبت گرا و مبتنى بر بذيرش و تعهد بر تو انمندىهاى منش ونش اين بيماران بود. نتايج يثزوهش نشان داد كه درمان مثبتكرا باعث افزايش توانمندىهاى منش و مؤلفههاى آن در زنان مبتلا به روماتيسم مفصلى شده است. نتايج اين يثوهش با نتايج فرنام و مددىزاده (Y.IV) مبنى بر اثربخشى آموزش مثبت نخرى بر حالت هاى روانشناختى مثبت (توانمندىهاى منش) دانش آموزان دختر دبيرستانى با نتايج مظلومى برم سبز و همكاران (19 (Y) مبنى بر

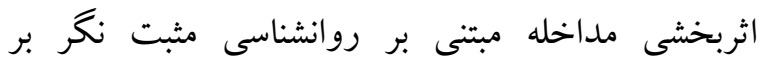

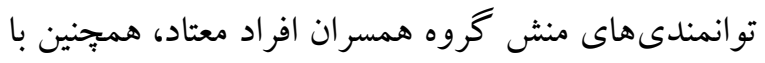
نتايج بشريور و همكاران (Y) (Y)، يعقوبى و نسائى مقدم

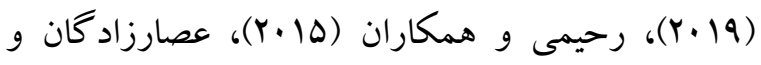
رئيسى (Y (Y) مبنى بر اثر بخش بودن درمان مثبت گرا بر ويز كى هاى مثبت، همسو است. 
هر گونه عملى جهت اجتناب يا كنترل اين تجارب ذهنى ناخواسته، بىاثر يا اثر معكوس دارد و موجب تشديد آنها مىشود. در مرحله دوم، بر آكاهى روانى فرد در لحظه حال افزوده مىشود؛ يعنى فرد از تمام حالات روانى، افكار و رفتار خود در لحظه حال آكاهى مىيابد (موسوى و بزرگك دشت، 19 (Y). در واقع، مكانيسم اصلى اثر گذارى اين روش درمانى، در جلسات درمانى اين بن بثزوهش متمركز بر اين نكته بود كه بيماران به جاى اين كه بر روى برطرفسازى و حذف عوامل آسيبزا تمركز نمايند، به ايجاد تمايل براى درگير شدن در اهداف و ورك

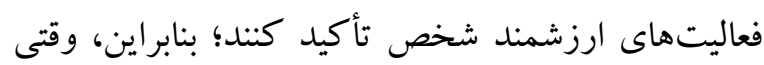
به بيماران آموزش داده مىشود كه هيجانات و احساسات خود را بدون به كار گيرى مكانيسمهاى دفاعى بيذيرند و بتواند فارغ از ارزيابى اغراق آميز تجارب درونى، به ديخر امور شناختى و رفتارى ارزشمند خود ادامه دهند، به طور معمول از ميزان فشار روانى وى كاسته شده و در نتيجه اين كاهش فشار روانى منجر به افزايش توانمندىهاى

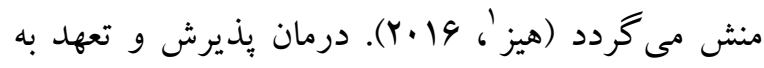
زنان در يزوهش حاضر كمك كرد آكاهى خود را افزايش دهند كه به نوعى منتهى به خرد و دانش مىشود، مشكلات خود را بدون اجتناب بيذيرند كه با مؤلفه شجاعت در ارتباط است، در روبروى با مشكلات نه آن را بزرگك جلوه دهند و نه ناديده بخيرند كه نوعى از اعتدال و ميانهروى به حساب مى آيد، با دنبال نمودن ارزشها و اهداف خود، به تعالى و فرا روندگى خود به ميز ان بيشترى دست بيدا كنند. همجنين نتايج اين بثزوهش نشان داد كه درمان مثبت گرا بر توانمندىهاى منش به طور كلى و مؤلفه هاى اعتدال و
در زنان مبتلا به روماتيسم مفصلى گرديد. هيج يثزوهش به بررسى اثربخشى درمان مبتنى بر يذيرش و تعهد بر توانمندى هاى منش در ايران نبرداخته است و در مقالات خارجى يافت نشد؛ لذا نتايج يثوهش با نتايج مشابه مقايسه مىشود. نتايج اين يثوهش با نتايج رضائيان و

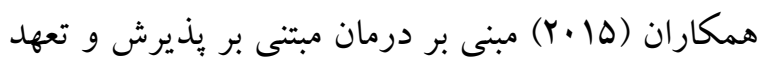

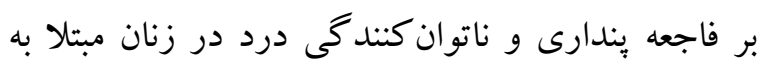
درد مزمن لكن، با نتايج ميرزايى دوستان و همكاران (Y. 19) مبنى بر اثربخشى درمان مبتنى بر بذيرش و تعهد

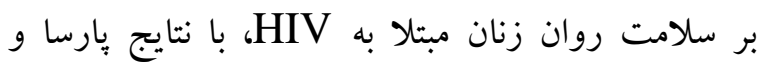

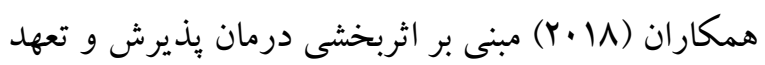
بر ارتقاى كيفيت زندگى، با نتايج خانبابايى و همكاران (Y.19) مبنى بر اثربخشى درمان مبتنى بر يذيرش و تعهد

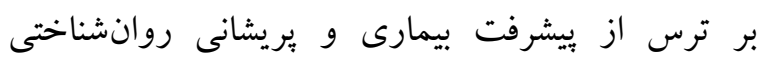

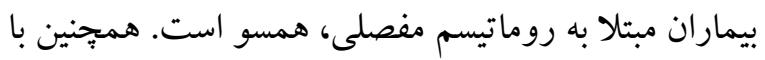
موسوى و دشت بزركى (Y9 (Y)، با نتايج مقبل اصفهانى و حقايق (19 (Y)، با نتايج فرخزاديان و همكاران (Y) (Y) و و

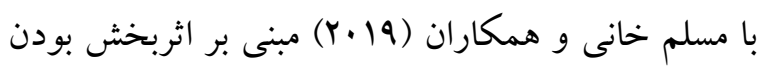

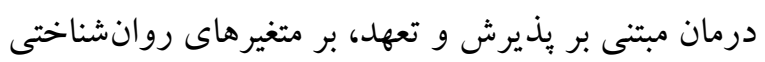
همخوانى دارد. در خصوص تبيين اثربخشى درمان يذيرش و تعهد بر تو انمندىهاى منش، مى توان كفت درمان بذيرش و تعهد با آكاه نمودن فرد از هيجانات مثبت و منفى، بذّيرش و ابراز به موقع آنها، نقش مهمى در كاهش مشكلات روانى و رفتارى و بهبود توانمندىهاى منش دوارد

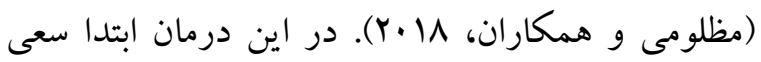
مىشود، يذيرش روانى فرد در مورد تجارب ذهنى (افكار، احساسات و غيره) افزايش يابد و متقابلاً اعمال كنترلى نامؤثر كاهش يابد. به بيمار آموخته مىشود كه

1. Hayes 
در صورت افزايش مىتوانند مقاومت افراد در برابر بيمارى را افزايش دهند (مظلومى برم سبز و همكاران،

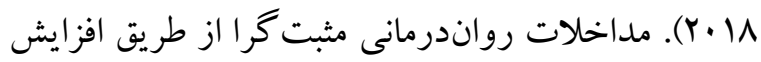
افكار و رفتارهاى مثبت به افراد در جبران برخى خطرات و كاهش ييامدهاى منفى آن كمك مى كند كه اين امر نه تنها از طريق كاهش هيجانات منفى بلكه بـه صسورت مستقيم نيز به افزايش و رشد توانمندىهاى منش در افراد منجر مى شود (لوماس ب، 19.ب). از طرفى افراد در جلسات

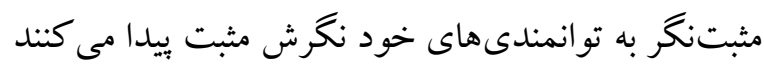
به جاى تمركز روى شكستها و دلمشغولى به حوادث ناگوارى كه در كذشته داشتهاند بر روى حوادث مثبت متمركز مى كنند. اين افراد بيروزىها و موفقيتهاى خود را به توانمندىهاى خود نسبت مى دهند. در شرايط سخت زندگى به منابع درونى خود تكيه مى كنند و مقابلههاى

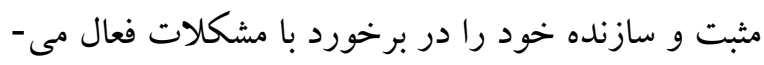

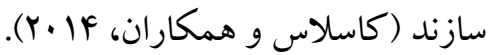

\section{نتيجه كيرى}

اين بررسى در خصوص مقايسه اثربخشى درمان مثبت گرا و يذيرش و تعهل بر توانمندىهاى منش در زنان مبتلا به به بـ بـ روماتيسم مفصلى بود. يافته ها نشان داد كه هر دو درمان

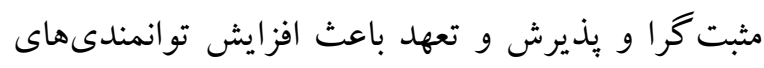
منش در اين بيماران شد. همجنين نتايج نشان داد كه درمان مثبت گرا بر توانمندىهاى منش به طور كلى و مؤلفههاى اعتدال و تعالى اثربخشتر از درمان بذيرش و تعهل بوده است. در بين اين دو درمان وجهه اشتراكاتى وجود دارد كه دليلى بر اثربخشى هر دو درمان بر توانمندىهاى منش بيماران بود مثل، تأكيد بر ارزشها،

2- Lomas
تعالى اثربخشى بيشترى نسبت به درمان يذيرش و تعهد

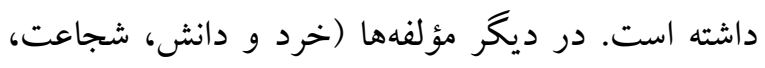
انسان دوستى و عدالت) بين درمان مثبت گرا و بذيرش و و تعهد تفاوت معنادارى وجود نداشت. بخشى از نتايج اين يثزوهش در مورد اثربخشتر بودن درمان مثبت گرا با نتايج

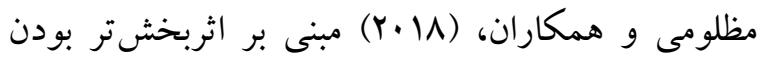
درمان مثبتنكر بر توانمندىهاى منش بيماران همسو است. قسمت ديخرى از نتايج يزوهش حاضر با نتايج يدالله يور و همكاران (Y) درمان مثبتنكر با بذيرش و تعهد بر سرمايههاى روانشناختى بيماران قلبى- عروقى و نيز با نتايج بهراد و همكاران (Y) (Y.M در مورد تفاوت نداشتن بين درمان مثبت گرا با بذيرش و تعهد بر ابعاد درد بيماران ميگرنى، همسوى دارد. در تبيين اثربخشتر بودن درمان مثبت گرا، مىتوان كفت در جلسات درمانى مثبت، بر روى فضايل، ويز گیىها و تجارب مثبت تأكيد مى كند؛ به اين ترتيب، در مداخلات درمانى مثبت گرا، انسانها به عنوان افرادى در نظر گرفته مىشوند كه داراى يتناسيل هاى ذاتى براى افزايش دادن تو انمندىهاى منش و فضايل هستند. از اين رو مداخلات مثبت گرا، مىتوانند مكملى براى مداخلات سنتى باشند كه هدف آنها، خلاصى از رنج است و اين دستاورد، مى تواند ميراث عملى روانشناسى مثبت باشد. بر اساس يثزوهشهايى كه در اين زمينه صورت كرفته است، هيجانهاى مثبت سبرى در برابر بيمارىها و عامل مهمى

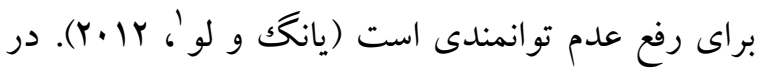

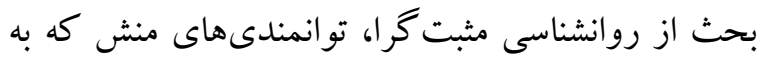

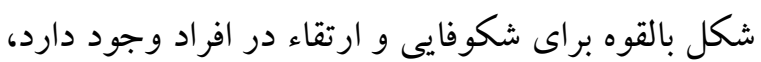

1- Young 
adults, Joumal Canadian Medical Association, 182(3): 246-256.

Arjmand Ghujur K, Mahmoud Aliloo M, Khanjani Z, Bakhshipour A. (2019). Effectiveness of Acceptance and Commitment Therapy (ACT) in Relapse Prevention in Methamphetamine Addict Patients. Yafte. 21(1):38-51. (In Persian)

Assarzadegan M, Raeisi Z (2019). The Effectiveness of Training Based on Positive-Psychology on Quality of life and Happiness of Patients with Type 2 Diabetes. Journal Quarterly of Health Psychology. 8(2). (In Persian)

Bahramirad M, Rafezi Z (2019). Predicting Pain Acceptance Based on Perceived Stress and Coping Strategies in individuals with Rheumatoid Arthritis. Joumal Quarterly Health Psychology, 7(4). (In Persian)

Basharpoor S, Kazemi N, Salehi M. (2018). The Effectiveness of Positive Group Psychotherapy on Self-Determination and Death Anxiety in Women with Breast Cancer. Sabzevar University of Medical Sciences. 25 (5). (In Persian)

Beheshtian F, Ahadi H, Elmy Manesh N, kraskian Mojembari A. (2018). The Comparison Effectiveness of Acceptance and Commitment Therapy and Stress Inoculation Training on Psychological capital in Infertile women. Joumal Quarterly Health Psychology, 7(3). (In Persian)

Behrad M, Makvand Hosseini S, Najafi M, Rezaei A, Rahimian Boogar E. (2018). Comparison of Effectiveness of Positive Psychotherapy and Acceptance and Commitment Therapy on Aspects of Paine in Patients with Migraine. Psychological Studies Faculty of Education and Psychology, 14.(1). (In Persian)

Casellas Grau A, Font A, Vives J. (2014). Positive psychology interventions in breast Cancer. A systematic review, Joumal Psycho Oncology, 23(1), 9-19.

Chaleshgar Kordasiabi M, Akhlaghi M, Askarishahi M, Sabzmakan L, Abbasi Shavazi M. (2016). Quality of Life and Related Factors in Rheumatoid Arthritis Patients. Joumal of
اهداف و توانمندىهاى افراد، انعطافيذيرى روانشناختى و ذهن آكاهى و تماس با لحظه جارى است. درمان مثبت گرا، با تقويت تاب آورى و تو انمندىها، بالا بردن سطح عاطفه مثبت و رضايت از زندگى و درمان يذيرش و تعهد، با بذيرش و اجتناب نكردن و فرارى نبودن از مشكلات به توانمندىهاى بيماران اين يُزوهش كمك كردند. از محدوديتهاى يثزوهش حاضر مىتوان به نمونه ئزوهش اشاره كرد كه فقط از بين بيماران شهر خرم آباد انتخاب شد، هر جُند در تعميم نتايج به ساير بيماران خوددارى شده است. از ديخر محدوديتها به مسئله نداشتن بيشينهى در مورد اثربخشى درمان بذيرش و تعهد بر توانمندىهاى منش مىتوان اشاره كرد. بيشنهاد مىشود به بررسى اثربخشى درمان يذيرش و تعهد بر توانمندىهاى منش بيماران ديخر برداخته شود. همجينين با توجه به اينكه درمان مثبت گر ا با درمانهاى ديخر كمتر مورد مقايسه قرار كرفته ؛ لذا بيشنهاد مىشود كه درمان مثبت گر ا با ساير درمانها مقايسه شود.

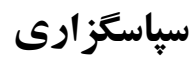
نويسند گان اين مقاله تشكر صميمانه خود را از مسئولان و معاونت بزّوهش و تحقيقات دانشگاه علوم بز شكى لرستان جهت كد اخلاق: IR.LUMS.REC.1398.292 و نيز از زنان مبتلا به روماتيسم مفصلى شهر خرم آباد كه در انجام اين ثيزوهش ما را يارى دادند، كمال تشكر و و قدردانى را ابراز مى دارند.

\section{References}

Amonoo HL, Barclay ME, ElJawahri A, Traeger LN, Lee SJ, Huffman JC, (2019). Positive Psychological Constructs and Health Outcomes in Hematopoietic Stemnations 
Health Research in Community. Autumn,2(3), 1-11. (In Persian)

Davoodi M, Shameli L, Hadianfard H. (2019). The Effectiveness of Acceptance and Commitment Therapy on Chronic Fatigue Syndrome and Pain Perception in People With Multiple Sclerosis. Joumal Iranian of Psychiatry and Clinical Psychology. 25(3),250-265. (In Persian)

Duan W. (2016). The benefits of personal strengths in mental health of stressed students: A longitudinal investigation. Journal Qual Life Res, 25(11), 2879-2888.

Ejei J, Sayadshirazy M, Gholamali Lavasani M, Kasaei Esfahani A. (2018). Compare the Effectiveness of Group Therapy Based on Acceptance and Commitment and CognitiveBehavioral Therapy on Reducing Anxiety of Mothers of Autistic Children, Joumal of Psychology, 22 (1), 3-21. (In Persian)

Farnam A, madadizade T. (2017). Effect of Positive Training on Positive Psychological States (Character Strengths) of Female High School Students. Joumal Positive Psychology Research, 1 (9), 61-75. (In Persian)

Farokhzadian AA, Ahmadian F, Andalib L. (2019). The Effectiveness of Acceptance and Commitment Therapy on the Severity of Symptoms and Quality of Life in Soldiers with Imitable Bowel Syndrome, Journal of Military Medicine, 1(21), 44-52. (In Persian)

Fatemi F, Manshaei G. (2016). The Effectiveness of Acceptance and Commitment Therapy Based on Pain Intensity Perception among Patients with Rheumatoid Arthritis in Isfahan. Joumal Res Behav Sci, 14(3): 296-301. (In Persian)

Hayes SC. (2016). Acceptance and Commitment Therapy, Relational Frame Theory, and the Third Wave of Behavioral and Cognitive Therapies-Republished Article. Joumal Behavior therapy, 47(6), 869-885.

Hermann C, Ofer J, Flor H. (2014). Covariation bias for ambiguous social stimuli in generalized social phobia. Joumal of Abnormal Psychology. 113(6), 646-53.
Izakian S, Mirzaian B, Hosseini SH. (2019). The Effectiveness of Acceptance and Commitment Therapy on Emotion Dysregulation and Self-Compassion Among Self-Harm Students. Journal of Thought \& Behavior in Clinical Psychology 14 (53),1726. (In Persian)

Jabbari M, Shahidi S, Panaghi L, Mazaheri MA. (2019). A Qualitative study of definitions of the adolescents' character strengths in Iran society. Journal of Research in Psychological Health, 64-80(In Persian)

Khanbabaei N, zahedi R, rafiepoor A. (2019). The effectiveness of acceptance and commitment therapy (ACT) on the psychological distress and fear of disease progression in patients with meumatoid arthritis. Joumal Quarterly of Health Psychology, 8 (4), 117-132. (In Persian)

Khodabakhsh R, Khosravi Z, Shahangian Sh. (2016). Effect of Positive Psychotherapy in Depression Symptoms and Character Strengths in Cancer Affected Patients. Joumal positive psychology, 1(1), 35-50. (In Persian)

Kobue B, Moch S, Watermeyer J. (2017) 'It's so hard taking pills when you don't know what they're for": a qualitative study of patients' medicine taking behaviours and conceptualisation of medicines in the context of rheumatoid arthritis. BMC Health Serv Res 17(1):303. https//doi.org/10.1186/s12913017-2246-8.

Lomas T. (2016). Towards a positive cross-cultural lexicography: Enriching our emotional landscape through 'untranslatable' words pertaining to well-being. Journal Posit Psychol, 11(5), 546-558.

Martinez Lopez JA, Garcia Vivar ML, Caliz R, Freire M, Galindo M, Hernandez MV, Lopez Longo FJ, Martinez Taboada V, Pego Reigosa JM, Rubio E, Trujillo E, VelaCasasempere P. (2017). Recommendations for the evaluation and management of patients with meumatic autoimmune and inflammatory diseases during the reproductive 
age, pregnancy, postpartum and breastfeeding. Journal Reumatol Clin 13(5),264-281.

Mazlomi Barmsabz A, Asgari P, Makvandi B, Ehteshamzadeh P, Bakhtiarpour S. (2019). Comparing the effectiveness of positivepsychological intervention and emotional regulation training on Nar- Anon group's Character-Strength. Joumal Anesth Pain. 6(4). (In Persian)

Mazlomi Barmsabz A, Asgari P, Makvandi B, Ehteshamzadeh P, Bakhtiarpour S. (2018). Comparing the effectiveness of positivepsychological intervention and emotional regulation training on Nar- Anon group's Character-Strength. Joumal Anesth Pain. 6(4). (In Persian)

Mirzaeidoostan Z, Zargar Y, Zandi Payam A. (2019). The Effectiveness of Acceptance and Commitment Therapy on Death Anxiety and Mental Health in Women With HIV in Abadan City, Iran Journal Iranian of Psychiatry and Clinical Psychology. 25(1),213. (In Persian)

Moghbel Esfahani S, Haghayegh S. (2019). Effectiveness of Acceptance and Commitment therapy on Resiliency, Meaning of Life and Family Functioning in Caregivers of Patients With Schizophrenia, Quarterly of "The Horizon of Medical Sciences.25(4), 298311. (In Persian)

Molavi P, Mikaeili N, Daneshvar S, Narimani M, Mehri S. (2015). The Role of Denial and Alexithymia on Pain Perception in Women With Breast Cancer. The Journal of Urmia University of Medical Sciences, 26(2). (In Persian)

Moslem Khani M. Ebrahimi ME, Sahebi A. (2019). The Effectiveness of Acceptance and Commitment Therapy (ACT) on Happiness and Hope of Hamedanian Multiple Sclerosis Patients. Joumal Pajouhan Scientific, 17 (2), 15-23. (In Persian)

Mousavi M, DashtBozorgi Z (2018). Effect of Acceptance and Commitment Group Therapy (ACT) on the Hardness and Perceived Stress Coefficient Among Patients with Type 2 Diabetes.. Iranian Journal of Health Education and Health Promotion, 5 (4) 311-319. (In Persian)

Namdari K. (2010). The standardization of the Practice and Values Test in Practice (VIA-IS) and the effectiveness of cognitive education in promoting hope on the level of the ability of depressed clients. PhD Thesis in Psychology. University of Esfahan. (In Persian)

Niemiec RM. (2018). Character strengths interventions: A field guide for practitioners. Canada: Journal Hogrefe Publishing. 4(6).

Parsa M, Sabahi P, Mohammadifar MA. (2018). The effectiveness of acceptance and commitment group therapy to improving the quality of life in patients with multiple sclerosis, Joumal of Clinical Psychology, 37(1). (In Persian)

Peterson C, Seligman MEP. (2004). Character strengths and virtues:A Handbook and Classification. Washington:, Journal American Psychological Association.3 (6).

Rashid T. (2008). Positive Psychotherapy.InS.J.Lopez (Ed.), Theencyclopedia of positive psychology. NY: WileyBlackwell.4(7).

Rashid T. (2015). Positive psychotherapy: A strengthbased approach, The Journal of Positive Psychology, 10(1), 25-40.

Rezaeian M, Ebrahimi A, Zargham M. (2015). The Effect of Acceptance and Commitment Therapy on Catastrophic and Disabling Pain in Chronic Pelvic Pain in Females, Joumal of Cognitive and Behavioral Sciences Research, 2(7), 17-30. (In Persian)

Ruch W, Weber M, Park N, Peterson C. (2014). Character strengths in children and adolescents: Reliability and initial validity of the German Values in Action Inventory of Strengths for Youth (German VIA-Youth). Eur. Joumal Psychol Assess, 30: 57-64.

Sadeghi F, Abolghasemi A, Kazemi R, Narimani M. (2019). The Effectiveness of Positive Cognitive - behavioral Therapy on Orientation of Life in Female Teachers with Chronic Fatigue Syndrome. Joumal of Cognitive and Behavioral Sciences Research 11 (2). (In Persian) 
qa مقايسه اثربخشى رواندرمانى مثبت كرا با درمان مبتى بر بذيرش و تعهد بر تو انمندى هاى منش زنان مبتلا به روماتيسم مفصلى

Sadeghi M. Biranvand Z. (2018). The effects training of positive thinking skills in the way of group study on positive emotion leaming and academic self-regulation in on grade girl high school students, Biquarterly Joumal of Cognitive Strategies in Leaming, 5 (9). (In Persian)

Seligman MEP, Emest RM, Gillham J, Peivich K, Linkins M. (2009). Positive education: Positive psychology and classroom interventions. Joumal Oxford Review of Education, 35, 293-311.

Teixeira V, Tam LS. (2018). Novel insights in systemic lupus Erythematous and atherosclerosis. Journal Frontiers in Medicine, 4, 262-288.

Yadollahpour MH, Fazeli Cebria M, Amin Kr. (2019). Comparing the Effectiveness of Positive Psychology with an Islamic Approach and Acceptance and Commitment Therapy (ACT) on the Psychological Capital of Cardiovascular Patients. Joumal Community Health 13(2), 11-22. (In Persian)

Yaghoobi A, Nesai Moghadam B. (2019). The Effect of Positive Psychology Intervention on the Psychological Well-Being of Adolescents (Persian). Iranian Journal of Psychiatry and Clinical Psychology; 25(1):14-25. http://dx.doi.org/10.32598/ ijpcp.25.1.14. (In Persian)

Young L, Lu Q. (2012). A pilot study of expressive positive intervention among Chinese-speaking breast cancer survivors. Joumal Health Psychology, 31(4), 548-551.

Zhang CQ, Leeming E, Smith P, Chung PK, Hagger MS, Hayes SC. (2018). Acceptance and commitment therapy for health behavior change: a contextuallydriven approach. Journal Frontiers in psychology, 8, 2350. 